\title{
Analisis Semiotika Roland Barthes (Pemaknaan Kata Tarekat dalam Surat Al-Jin 16)
}

\author{
Muhammad Arif \\ Pascasarjana UIN Sunan Kalijaga \\ ariefbinyunus@gmail.com
}

\begin{abstract}
Abstrak
Kajian tentang semiotika ini sebenarnya sudah ada sejak zaman Plato dan Aristoteles dan zaman di bawahnya, akan tetapi belum menjadi kajian yang kokoh dan sistematis sebagaimana semiotika yang dirumuskan oleh dua tokoh modern yang disebut sebagai bapak semiotika yaitu Ferdinand De Saussur dan Charles Sanders pierce. Berbicara mengenai semiotika modern, Roland Barthes merupakan salah satu tokoh struktural yang mengembangkan teori semiotika dengan sedemikian rupa, Sebagai teori yang mengkaji tentang tanda, dalam pengertian yang lebih luas, semiotika diartikan sebagai studi sistematis mengenai produksi, interpretasi tanda, cara kerjanya serta manfaatnya. Dalam hal ini, bahasa dianggap sebagai sistem tanda, adapun tanda, Oleh Saussure didefinisikan sebagai kombinasi antara konsep (concept) / signifie (petanda) dan citra akustik (image acoustiqe)/ signifiant (penanda).Selanjutnya, sebagai langkah aplikatif terhadap teori semiotika Roland Barthes ini, maka mengungkap makna yang terkandung dalam kata Tarikat dalam Al-Qur'an surat Al-Jin ayat 16 dianalasis dengan menggunakan langkah-langkah yang ditawarkan oleh Barthes dalam semiotiknya, bahwa pada wilayah bahasa, tarikat (jalan) merupakan penanda dari sebuah pendekatan diri terhadap Tuhan. Bentukan dari penanda dan petanda tersebut (Tarikat merupakan bentuk ketakwaan terhadap Tuhan), akan berfungsi untuk menjadi penanda dalam wilayah mitos. Pesan Allah yang menyatakan bahwa Dan bahwasanya jikalau mereka tetap berjalan lurus di atas jalan itu (agama Islam). Atau dalam artian yang lain, seseorang wajib memenuhi perintah Tuhan.
\end{abstract}

Kata Kunci: Semiotika,Roland Barthes, Tarekat, Al-Jin-16

\section{PENDAhuluan}

Roland Barthes memperkenalkan konsep tentang mitos. Mitos merupakan salah satu alat komunikasi untuk menyampaikan pesan. Bagi Roland Barthes, mitos tidak hanya berupa tuturan oral, namun tuturan dapat berbentuk tulisan, fotografi, olah raga, lukisan, atau iklan ${ }^{1}$. Dapat dikatakan bahwa mitos adalah semua yang mempunyai modus representasi yang memerlukan interpretasi untuk memahami maksudnya. Misalnya untuk mengetahui arti (meaning) suatu lukisan, belum tentu

${ }^{1}$ Roland Barthes, Element of Semiology terj. Annette Lavers and Colin Smith (New York: Hill and Wang, 1981), h. 1. 
dapat ditangkap secara langsung. Untuk mendapatkan artinya harus melalui proses signifikansi sehingga dapat diterima oleh akal. Dengan demikian, mitos bukan hanya sebagai suatu objek, konsep, atau ide yang stagnan. ${ }^{2}$

Mitos merupakan bagian dari kajian semiologi, yakni ilmu yang mempelajari tentang tanda dan petanda. Semiologi berurusan dengan bentuk yang membuat suara, imaji, gerak, dan lainnya yang berfungsi sebagai tanda. Mitos tidak luput dari tanda-tanda. Misalnya, pada sebuah lukisan burung. Burung dalam lukisan tersebut pasti merupakan simbol atau tanda dari sebuah gagasan atau pesan. Roland Barthes membuat tiga elemen dasar dalam menganalisis mitos, yakni penanda (signifier), petanda (signified), dan tanda. Ketiga elemen ini nantinya akan sangat berfungsi dalam menganalisis mitos, dan keberadaan setiap elemennya sangat dibutuhkan. Misalnya, ketika suatu petanda tidak ada yang bisa digunakan sebagai penanda, maka tanda pun tak akan terwujud, dan suatu penanda sudah pasti merupakan bentuk dari yang ditandakan (petanda). ${ }^{3}$

Sebagai langkah awal, penulis gambarkan sistematika analisis mitos oleh Roland Barthes dalam sebuah skema:

\begin{tabular}{|c|c|}
\hline 1. Signifier & 2. Signified \\
3. Sign & II. SIGNIFIED \\
\hline III. SIGN & Sistem linguistik \\
\hline \multicolumn{2}{|c|}{ Sistem mitos } \\
\hline
\end{tabular}

\section{Tinjauan Pustaka}

Sebagai kajian yang mengkaji tanda-tanda yang terdapat dalam masyarakat, semiotika memiliki ruang lingkup kajian yang luas. Sementara Al-Qur'an dengan

${ }^{2}$ Aart van Zoest, "Interpretasi dan Semiotika" dalam Panuti Sdjiman dan Aart van Zoest (ed.), Serba- serbi Semiotika (Jakarta: Gramedia Pustaka Utama, 1996), h. 1

${ }^{3}$ Roland Barthes, Elemnets of Semiologi, h. 2 
menggunakan bahasa sebagai media merupakan lahan subur bagi kajian semiotika ini.

Dalam hal ini, teks al-Qur'an merupakan sekumpulan tanda yang di dalamnya terdapat hubungan dialektika antara signifiant (penanda) dan signifie (petanda). Penanda al-Qur'an adalah wujud teks yang berupa bahasa Arab, meliputi: huruf, kata, kalimat, ayat, surat maupun hubungan masing-masing unsur. Kompleksitas unsur-unsur yang saling berhubungan tersebut juga termasuk tanda alQur'an.Sedangkan, petanda al-Qur'an merupakan aspek mental atau konsep yang berada di balik penanda al-Qur'an.Hubungan antara penanda dan petanda al-Qur'an ditentukan oleh konvensi yang melingkupi teks al-Qur'an.

Dengan demikian, Semiotika Roland Barthes ini dapat digunakan untuk menganalisis kata "tarikat" pada ayat 16 surat Al-Jin di bawah ini

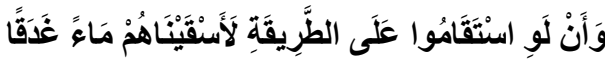

Artinya

"Dan kalau sekiranya mereka tetap berjalan lurus di atas jalan (tarekat) itu, niscaya Kami tetap menurunkan air hujan dari langit (memberi minum kepada mereka air yang segar)".

Ayat diatas mengindikasikan tengtang makna tarekat, yang sering dijadikan rujukan oleh orang-orang yang berkecimpung diranah tarikat.Mengapa al-Qur'an menggunakan kata tarikat sebagai simbol jalan untu mendapatkan pertologan Tuhan?, tidakkah ada kata lain selain tarikat untuk menunjukkan jalan yang lebih baik contoh misalnya kata الصِّرَاطَ dalam surah al-Fatihah?. Jawabannya mungkin bisa dilihat dari aspek kondisi sosial turunnya ayat tersebut dan melihat lebih jauh lagi makna subtansial tarikat yang akan dibahas dibawah ini.

Dalam dimensi tasawuf dikenal pembagian pegertian syariat, tarekat, hakekat dan ma'rifat. Syariat diartikan sebagai peraturan, tarekat adalah pelaksanaannya, hakekat merupakan keadaannya sedangkan ma'rifat adalah tujuan

Kata ash-irat terambil dari akar kata saratha, karena huruf sinbergandengan dengan huruf $\mathrm{ra}$, maka huruf sin terucapkan shad menjadisiratatau zai menjadi zirath, yang asal katanya bermakna menelanKemudian, sekelompok pakar bahasa menegaskan bahwa kata șirâtberasal dari sarth, yang berarti "tempat berlalu (jalan)". Kata sirat biasanyadigunakan untuk jalan yang tidak berkelok.Kendati demikian, tidak berartipula jalan kebaikan, kecuali jika diiringi kata sifat atau idlafah kata tersebutbermakna kebaikan dan hidayah.Muhammad Kamil Hasan al-Mahami, Ensiklopedi Al-Qur'an Tematis, (Jakarta: Al-Maktab Al-Alamiy, t,th), h. 57-58 
akhir. ${ }^{5}$ Banyak kalangan yang menilai bahwa tasawuf termasuk tarekat di dalamnya adalah bid'ah padahal pada kenyataan tidak demikian. Termasuk para orientalis yang meyakini bahwa tasawuf adalah ajaran yang ter-influence oleh ajaran agamaagama sebelum islam termasuk Nasrani, maupun Budha yang sering dihubungkan dengan mistisme.

Seperti apa yang pernah dikatakan Annemarie Schimmel, dia berkata "Many scholars were and are still inclined to accept Indian (Hindu) Influenceon formative period of Sufism ", Di dalam ajaran tasawuf sebenarnya mencakup hal tentang penyucian jiwa (tazkiyah an-nafs) melalui metode-metode tertentu yang pada akhirnya mengakibatkan perbedanya madzhab tasawuf yang dinamakan "tariqah" (tarekat) karena perbedaan kodifikasi antar ulama'.

Tarekat dalam bahasa arab yaitu thariqah yang berarti jalan, keadaan, aliran, atau garis pada sesuatu. Menurut istilah tasawuf, tarekat berarti perjalanan seorang salik (pengikut tarekat) menuju Tuhan dengan cara mensucikan diri atau perjalanan yang harus ditempuh secara rohani, maknawi oleh seseorang untuk dapat mendekatkan diri sedekat mungkin kepada Allah SWT. Menurut Syekh Amin alKurdi tarekat ialah cara mengamalkan syariat dan menghayati inti syariat itu dan menjauhkan diri dari hal-hal yang bisa melalaikan pelaksanaan dan inti serta tujuan syariat. Sehingga secara umum tarekat diartikan jalan, cara yang ditempuh guna mengenal dan mendekatkan diri pada Allah Swt. ${ }^{7}$

Untuk mendapatkan pengertian yang utuh dari suatu istilah, pertama-tama biasanya diuraikan tentang pengertian bahasa etimologi dari istilah tersebut. Demikian pula dengan term tarekat yang berasal dari bahasa Arab طريقة yang merupakan bentuk mashdar (kata benda) dari kata طرق- يطرق- طريقة yang memiliki arti الكيفية (jalan, cara), الأسلوب (metode, sistem), المذهب (madzhab, aliran, haluan), dan الحالة (keadaan). ${ }^{8}$ Pengertian ini membentuk dua makna istilah yaitu metode bagi ilmu jiwa akhlak yang mengatur suluk individu dan kumpulan sistem pelatihan ruh yang berjalan sebagai persahabatan pada kelompok-kelompok persaudaraan Islam. ${ }^{9}$ Hanya saja tarekat dalam pembahasan ini bukan sekedar jalan atau metode

43

${ }^{5}$ Abubakar Aceh, Pengantar Ilmu Tarekat, (Solo; Ramadhani,1996),h. 68
${ }^{6}$ Wahid Bakhs Rabbani, Islamic Sufism, (Kuala Lumpu; A.S Norden,1995),h.

${ }^{7}$ Sri Mulyati, Tasawuf Nusantara, (Jakarta; Prenada Media, 2006),h. 98

${ }^{8}$ Ahmad Warson Munawwirr, Al Munawwir;Kamus Arab-Indonesia (Cet; XIV, Surabaya; Pustaka Progressif, 1997), h. 849.

${ }^{9}$ Muhammad Sabit al Fandi, dkk.,Dairat al Ma'arif al Islamiyah (jil. XV, Teheran, Intisyirat Jahannam, t.th), h. 172. 
biasa, tetapi jalan dan metode tersebut penekanannya pada hubungan antara hamba dengan Tuhannya.

Dari pengertian di atas dapat dipahami bahwa tarekat adalah suatu jalan menuju Tuhan (Allah) yang dapat membawanya kepada kebahagiaan dunia akhirat. Jalan tersebut dalam lingkup tasawuf memiliki makna ganda sebagaimana disebutkan di atas. Pertama, pada abad ke-9 dan ke-10 Masehi atau sekitar abad ke1 dan ke-2 Hijriah berarti cara pendidikan akhlak dan jiwa bagi mereka yang menempuh hidup sufi. Kedua, sesudah abad ke-11 M atau abad ke-3 H. Tarekat mempunyai pengertian sebagai suatu gerakan yang lengkap untuk memberikan latihan-latihan rohani dan jasmani pada segolongan kaum muslimin menurut ajaran dan keyakinan tertentu. ${ }^{10}$

Dalam pengertian pertama, istilah tarekat masih berupa teori ${ }^{11}$ yang digunakan untuk memperdalam syariat sampai kepada hakikatnya dengan melalui tingkat-tingkat pendidikan tertentu berupa maqamat dan ahwal. Dengan kata lain tarekat merupakan usaha pribadi seseorang melewati jalan yang mengantarkannya menuju Allah SWT, jalan yang dimaksud sesuai penjelasan Syekh Muhammad Nawawi al Banteni al Jawi adalah melakukan hal-hal yang bersifat wajib dan sunat, meninggalkan sesuatu yang bersifat larangan, menghindarkan diri dari melakukan sesuatu yang boleh secara berlebihan serta berusaha untuk bersikap hati-hati melalui upaya mujahadah dan riyadhah. ${ }^{12}$ Sedangkan Haidar Bagir menjelaskan bahwa tarekat dalam arti yang pertama adalah jalan spiritual oleh seorang pejalan (salik) menuju hakikat. Untuk makna ini, ia identik dengan tasawuf. ${ }^{13}$

10 Asmaran As, Pengantar Studi Tasawuf (Cet; II, Jakarta; RajaGrafindo Persada, 2002),h. 99-100.

${ }^{11}$ Sebenarnya kurang tepat bila dikatakan bahwa tarekat sekalipun pada masa-masa awal- dipahami sekedar teori yang digunakan untuk memperdalam syariat. Namun sekalipun demikian, pemaknaan tersebut ingin mengingatkan bahwa antara syariat dan tarekat tidak dapat dipisahkan karena tarekat merupakan suatu cara yang harus ditempuh, maka tidak dibenarkan meninggalkan syariah. Bahkan melaksanakan tarekat berarti melaksanakan syariah.

${ }^{12}$ Muhammad Nawawi al Jawi, Syarh Maraqi al 'Ubudiyah 'ala Matn Bidayat al Hidayat (Semarang; Toha Putra, t.th),h. 4.

${ }^{13}$ Sekalipun dalam kajian tasawuf, tarekat termasuk salah satu aspek di dalamnya di samping istilah syariat hakikat dan makrifat.Namun dalam pengertian ini Tasawuf dapat diartikan sebagai usaha dalam menguatkan rohani dan mengesampinkan jasmaniah untuk mengenal Tuhan dengan segala kesempurnaannya. Dengan kata lain tasawuf adalah penyucian hati untuk menanamkan karakter dan akhlak mulia, sehingga dipahami bahwa tasawuf pada 
Dalam pengertian yang kedua, tarekat adalah kelompok-kelompok pengikut ajaran tasawuf yang menekankan praktik-praktik ibadah dan zikir secara kolektif yang diikat oleh aturan-aturan tertentu, di mana aktifitasnya bersifat duniawi dan ukhrawi. Dengan kata lain, ia dapat dipahami sebagai suatu hasil pengalaman dari seorang sufi yang diikuti oleh para murid, menurut aturan/cara tertentu yang bertujuan untuk lebih mendekatkan diri kepada Allah SWT. Pengalaman sufi berupa tata cara zikir, riyadhah, doa-doa yang telah diamalkan dan menurutnya sang sufi telah berhasil mendekatkan diri sang sufi kepada Tuhan, inilah yang disusun sedemikian rupa menjadi aturan/tata cara yang baku, yang juga harus diikuti oleh murid-murid tarekat. ${ }^{14}$ Khusus dalam makalah ini, yang dimaksudkan dengan istilah tarekat adalah menurut pengertian yang kedua.

Karena pengalaman sufi sifatnya individual dalam artian sangat mungkin tidak sama antara satu sufi dengan sufi lainnya, maka dalam aplikasinya muncul tata cara dan atau aturan yang berlainan pula. Lebih jauh muncullah tarekat-tarekat dengan nama dan kaifiyat yang bermacam-macam. Sebagai contoh, Syekh Abdul Qadir al Jailani pendiri tarekat Qadiriyah selalu menekankan pada pensucian diri dari nafsu dunia.Karena itu, dia memberikan beberapa petunjuk untuk mencapai kesucian diri yang tertinggi.Adapun beberapa ajaran tersebut adalah taubat, zuhud, tawakal, syukur, ridha dan jujur. ${ }^{15}$ Bahkan di antara praktik spiritual yang diadopsi oleh tarekat ini adalah zikir (terutama melantunkan asma' Allah berulangulang).Dalam pelaksanaanya terdapat berbagai tingkatan penekanan dan intensitas.Ada zikir yang terdiri atas satu, dua, tiga dan empat. ${ }^{16}$ Praktik zikir dapat dilakukan bersama-sama, dibaca dengan suara keras atau perlahan, sambil duduk membentuk lingkaran setelah shalat, pada waktu subuh maupun malam hari.Setelah melakukan zikir, pelaku tarekat ini dianjurkan untuk melakukan apa yang disebut dengan pas al anfas yakni mengatur napas sedemikian rupa sehingga dalam proses menarik dan menghembuskan napas, asma' Allah bersikulasi dalam tubuh secara otomatis.Kemudian ini diikuti dengan muraqabah dan kontemplasi. Hanya saja dari sekian banyak pengalaman pribadi para sufi tampaknya terdapat beberapa aturan

dasarnya adalah tatanan moralitas. Lihat Haidar Bagir, Buku Saku Tasawuf (Cet; II,Bandung; Mizan Pustaka, 2006), h. 14

230

${ }^{14}$ M. Alfatih Suryadilaga, dkk., Miftahus Sufi (Yogyakarta; Teras, 2008), h.

$15 \mathrm{Hj}$. Sri Mulyati, dkk., Mengenal dan Memahami Tarekat-Tarekat Muktabarah di Indonesi a (Cet. I Jakarta; Kencana, 2004), h. 38.

${ }^{16}$ Untuk lebih jelasnya mengenai bentuk-bentuk zikir tersebut dapat dilihat pada karya-karya Syekh Abdul Qadir al Jailani, misalnya Ghunyat li Thalibi Thariq al Haq, al Fath al Rabbani dan Futuh al Ghayb. 
dan cara yang bisa dikategorikan dalam kesepakatan mereka, yaitu; mendalami ilmu yang berkaitan dengan syariah, mengendalikan nafsu untuk menghindari dosa, memperbanyak zikir dan doa tertentu, serta tidak meringankan amaliah-amaliah yang dilakukan. ${ }^{17}$

Dari pengertian di atas terdapat indikasi bahwa substansi dari sebuah tarekat adalah التقرب الى الله (pendekatan diri kepada Allah SWT), hal ini dapat dipahami dari sekian banyak penjelasan ulama utamanya yang terkait dengan pengertian tarekat. Misalnya saja Al Habib Asy Syaikh Al Sulthan Muhammad Sayyid Imaan bin Abdul Hakim Al Aydrus mengatakan bahwa tarekat adalah mengarahkan maksud (tujuan) kepada Allah Ta'ala dengan ilmu dan amal. Dikatakan juga bahwa tarekat merupakan perbuatan nafsaniyah yang tergantung kepada sir (rahasia) dan ruh dengan melakukan taubat, wara', muhasabah,muraqabah, tawakal, ridha, taslim, memperbaiki akhlak, menyadari akan kekurangan dan cela pada dirinya, dan atau mengerjakan ibadah hanya karena mengharapkan keridha' an Allah SWT serta ingin mendapat Nur Makrifat. ${ }^{18}$

Kaitannya dengan hal ini, Asmaran As mengutip salah satu riwayat yang menunjukkan bahwa Ali bin Abi Thalib pernah bertanya kepada Rasulullah SAW, katanya "Ya Rasulallah, manakah jalan (tarekat) yang paling dekat untuk sampai kepada Tuhan?" Rasulullah SAW menjawab, "Tidak ada yang lain kecuali zikir kepada Allah". ${ }^{19}$ Dengan demikian jelaslah bahwa dalam menempuh jalan untuk bertemu Allah, orang harus memperbanyak zikir kepada-Nya, di samping melakukan latihan dan perjuangan yang memerlukan keuletan, kesungguhan dan kesabaran.Jadi sekali lagi, tarekat merupakan upaya pendekatan diri kepada Allah yang teraplikasi lewat zikir yang banyak kepada-Nya. Akan tetapi, tarekat

${ }^{17}$ Ummu Kalsum, Ilmu Tasawuf (Cet;I, Makassar; Yayasan Fatiya, 2003), h. 116.

${ }^{18}$ Al Habib al Syaik al Sulthan Muhammad Sayyid Iman bin Abdul Hakim al Aydrus, Pelita Dalam Meniti Jalan "Thariqat" ; Adab dan Kelakuan Kaum Sufi (Makassar; Pustaka Refleksi, 2006), h. 1-2.

${ }_{19}$ Penulis belum menemukan dengan pasti sumber riwayat di atas, hanya saja makna yang terkandung di dalamnya selaras dengan pertanyaan sahabat kepada Nabi sebagaimana riwayat yang disampaikan oleh Imam al Turmudzi : , bahwasanya seseorang pernah berkata kepada Nabi, "Ya Rasulallah, sesuangguhnya syariat-syariat Islam terlalu banyak menurutku, karenanya beritakan kepadaku suatu amal yang bisa aku jadikan pegangan", Rasulullah SAW menjawab, "Hendaknya lidahmu senantiasa basah untuk berzikir kepada Allah". Abu Isa Muhammad bin Isa bin Saurah al Turmudzi, Sunan al Turmudzi (jil. V, Beirut; Dar al Fikr, 1994), h. 458. 
merupakan pengalaman pribadi sehingga aplikasi tersebut terkadang berbeda antara satu dengan yang lain. Itulah sebabnya, dikatakan bahwa tidak ada batasan mengenai jumlah terakat itu, karena setiap manusia mestinya harus mencari dan merintis jalannya sendiri, sesuai dengan bakat dan kemampuan ataupun taraf kebersihan hati mereka masing-masing. ${ }^{20}$ Banyak ungkapan ulama sufi dalam menggambarkan jalan-jalan tersebut, di antaranya Abu Thalib al Makki dalam kitabnya Quwwat al Qulub menyebutkan : الطرق إلى الله بعد الخليقة "jalan-jalan menuju Allah sebanyak jumlah makhluk", ini berarti bahwa setiap orang mesti sebaiknya mencari jalan sesuai dengan kemampuannya.

\section{METODE PENELITIAN}

\section{A. Jenis Penelitian}

Penelitian ini merupakan jenis penelitian kepustakaan (library research), sehingga sumber atau data yang digunakan dalam penelitian ini merupakan data yang berasal dari literatur-literatur pustaka seperti artikel-artikel, tesis, disertasi, ataupun buku-buku yang membahas tentang Semiotika Ronald Barthes dengan objek kajian kata tarekat dalam Surah Al-Jin 16.

\section{B. Sumber Penelitian}

Dalam penelitian ini, sumber atau data terbagi menjadi dua, yakni sumber primer dan sekunder. Adapun sumber primer penelitian ini adalah Semiotika Ronald Barthes.Sementara sumber sekunder adalah tesis, disertasi, ataupun buku-buku yang membahas tentang artikel jurnal, kata tarekat dalam Surah Al-Jin 16 . maupun secara umum.

\section{Analisis Data}

Sumber-sumber tersebut di atas kemudian akan dianalisis dengan menggunakan metode deskriptif-analitik, yakni mendeskripsikan sekaligus menganalisis sumber-sumber yang telah dikumpulkan secara sistematik sehingga mencapai kesimpulan yang objektif. Selain itu, sebagai langkah aplikatif terhadap teori semiotika Roland Barthes ini, maka mengungkap makna yang terkandung dalam kata Tarikat dalam Al-Qur'an surat Al-Jin ayat 16 dianalasis dengan menggunakan langkah-langkah yang ditawarkan oleh Barthes dalam semiotiknya

${ }^{20}$ Simuh, Tasawuf dan Perkembangannya dalam Islam (Cet; II, Jakarta; RajaGrafindo Persada, 1997), h. 40. 


\section{HASIL PENELITIAN}

Setelah menjelaskan pengertian subtansial ayat tentang tarikat dan berbagai defenisi tentang tarikat, maka dapat disimpulkan bahwa tarikat tersebut memiliki arti الكيفية (jalan, cara), الأسلوب (metode, sistem), الذهب (madzhab, aliran, haluan), dan (keadaan). Perumpamaan tarikat (jalan) tersebut merupakan sebuah pesan yang disampaikan oleh Sang pembuat pesan. Untuk memahami pesan tarikat tersebut, dapat digunakan pisau mitologi Roland Barthes.

\begin{tabular}{|c|c|c|c|c|}
\hline & Bahasa & $\begin{array}{l}\text { 1. Penanda } \\
\text { Tarikah }\end{array}$ & \begin{tabular}{lr}
\multicolumn{2}{c}{ 2. Penanda } \\
(Jalan & untuk \\
sampai & kepada \\
Tuhan) & \\
\end{tabular} & \\
\hline Mitos & & $\begin{array}{ll}\text { 3. } & \text { Tanda } \\
\text { I. Suatu cars } \\
\text { sampai ke }\end{array}$ & $\begin{array}{l}\text { dilakukan untuk } \\
\text { uhan }\end{array}$ & $\begin{array}{l}\text { II. konsep } \\
\text { suatu jalan } \\
\text { menuju } \\
\text { Tuhan } \\
\text { (Allah) } \\
\text { yang dapat } \\
\text { membawan } \\
\text { ya kepada } \\
\text { kebahagiaa } \\
\text { n dunia } \\
\text { akhirat }\end{array}$ \\
\hline \multicolumn{5}{|c|}{ III.Pemaknaan } \\
\hline
\end{tabular}

Melihat bagan di atas, dalam wilayah semiologi yang pertama, yakni wilayah bahasa, tarikat merupakan penanda dari sebuah jalan keselamatan. Bentukan dari penanda dan petanda tersebut (jalan untuk sampai kepada Tuhan), akan berfungsi menjadi penanda dalam wilayah mitos yang disebut dengan bentuk (lihat angka romawi I). Bentuk berkorelasi dengan konsep (lihat angka romawi II) menghasilkan sebuah makna konotasi (lihat angka romawi III). Makna konotasi ini merupakan makna yang dapat kita gunakan untuk memahami maksud dari pesan ayat di atas.

Pesan Allah yang menyatakan bahwa "dan bahwasanya jikalau mereka tetap berjalan lurus di atas jalan itu (agama Islam), benar-benar Kami akan memberi 
minum kepada mereka air yang segar (rezeki yang banyak). Untuk Kami beri cobaan kepada mereka dengan melaluinya."

Dari sedikit ulasan di atas, dapat diambil kesimpulan bahwa mitologi Roland Barthes dapat dijadikan sebagai alat bantu untuk memahami ayat-ayat alQur'an. Tidak semua wahyu Allah dalam al-Qur'an dapat dipahami secara langsung, karena terkadang Allah menggunakan perumpamaan-perumpamaan untuk menyampaiakan pesan-Nya.Perumpamaan-perumpamaan dalam al-Qur'an sendiri menjadikan al-Qur'an indah dibaca dan mendorong kita untuk mau berpikir, berusaha mencari maksud pesan Allah.

\section{PENUTUP}

\section{Kesimpulan}

setelah menjelaskan panjang lebar tentang semiotika Roland Barthes dan aplikasinya terhadap makna kata tarikat dalam ayat 16 yang terdapat dalam surat alJin, maka dapat disimpulkan menjadi beberapa poin di bawah ini:

1. Semiotika Roland Barthes merupakn pengembangan dari teori lingustik Saussure, Barthes banyak meminjam konsep lingusitik struktural, hal tersebut tampak pada klasifikasi elemen-elemen semiologi Barthes yang terdiri dari 4 konsep secara dikotomis, diantaranya adalah Langue-Parole, sintagmatiksitem/paaradigmatik, signifier-signifiant, denotation- konotation. Selain itu, Barthe dalam semiologinya juga mengambang sistem pertandaan kedua menjadi mitos, mitos merupakan tipe wicara yang terbentuk dari berbagai hal yang harus disampaikan sebagai wacana.

2. Di dalam mitos (sistem pertandaan kedua/sistem konotasi) memiliki dua sistem semiologis,pertama sistem bahasa( denotation) dan mitos (konotation). Tanda dalam sistem bahasa memiliki sifat ganda yaitu sebagai tanda bahasa yang disebut dengan mean (arti) dan Penanda dari sistem mitos yang disebut form (bentuk) kemudian berhubungan dengan petanda (konsep) yang menjadi tanda dalam sistem mitos disebut signifikansi/pemaknaan yang merupakan keseluruhan dari sistem semiologis. Jadi mitos memiliki dua pemaknaan yaitu makna denotasi dan makna konotasi. Sedangkan pembacaan terhadap mitos dikembalikan pada sifat awal mitos ( sifat ganda mitos antara Tanda dan penanda) ada 3 tipe model pembacaan berdasarkan hal tersebut, diantaranya adaalah pembacaan ditekankan pada makna, pembacaan pada bentu dan pembacaan pada keduanya (bentuk dan makna).

3. Sebagai contoh aplikasi teori semiotika Roland Barthes, maka akan digunakan untuk mengkaji kata Tarikat dalam Al-Qur'an surat Al-Jin ayat 16 dianalasis dengan menggunakan langkah-langkah yang ditawarkan oleh Barthes dalam semiotiknya, bahwa pada wilayah bahasa, tarikat (jalan) merupakan penanda dari sebuah pendekatan diri terhadap Tuhan. Bentukan dari penanda dan petanda 
tersebut (Tarikat merupakan bentuk ketakwaan terhadap Tuhan), akan berfungsi untuk menjadi penanda dalam wilayah mitos. Pesan Allah yang menyatakan bahwa Dan bahwasanya jikalau mereka tetap berjalan lurus di atas jalan itu (agama Islam). Atau dalam artian yang lain, seseorang wajib memenuhi perintah Tuhan.

\section{DAFTAR PUSTAKA}

Aart van Zoest, "Interpretasi dan Semiotika" dalam Panuti Sdjiman dan Aart van Zoest (ed.), Serba- serbi Semiotika, Jakarta: Gramedia Pustaka Utama, 1996.

Aceh, Abubakar, Pengantar Ilmu Tarekat, Solo; Ramadhani,1996.

al Aydrus, Al Habib al Syaik al Sulthan Muhammad Sayyid Iman bin Abdul Hakim, Pelita Dalam Meniti Jalan "Thariqat" ; Adab dan Kelakuan Kaum Sufi, Makassar; Pustaka Refleksi, 2006.

al Fandi, Muhammad Sabit, dkk., Dairat al Ma'arif al Islamiyah, jil. XV, Teheran, Intisyirat Jahannam, t.th.

al Jawi, Muhammad Nawawi, Syarh Maraqi al 'Ubudiyah 'ala Matn Bidayat al Hidayat, Semarang; Toha Putra, t.th.

al Turmudzi, Abu Isa Muhammad bin Isa bin Saurah, Sunan al Turmudzi, jil. V, Beirut; Dar al Fikr, 1994.

al-Mahami, Muhammad Kamil Hasan, Ensiklopedi Al-Qur'an Tematis, Jakarta: AlMaktab Al-Alamiy, t,th.

As, Asmaran, Pengantar Studi Tasawuf, Cet; II, Jakarta; RajaGrafindo Persada, 2002.

Bagir,Haidar, Buku Saku Tasawuf, Cet; II,Bandung; Mizan Pustaka, 2006.

Barthes, Roland, Element of Semiology terj. Annette Lavers and Colin Smith, New York: Hill and Wang, 1981.

Hj. Sri Mulyati, dkk.,Mengenal dan Memahami Tarekat-Tarekat Muktabarah di Indonesia Cet. I Jakarta; Kencana, 2004.

Kalsum, Ummu, Ilmu Tasawuf, Cet;I, Makassar; Yayasan Fatiya, 2003.

Mulyati, Sri, Tasawuf, Nusantara, Jakarta; Prenada Media, 2006.

Munawwirr,Ahmad Warson, Al Munawwir ; Kamus Arab-Indonesia, Cet; XIV, Surabaya; Pustaka Progressif, 1997.

Rabbani, Wahid Bakhs, Islamic Sufism, Kuala Lumpu; A.S Norden,1995. 
Simuh, Tasawuf dan Perkembangannya dalam Islam, Cet; II, Jakarta; RajaGrafindo Persada, 1997.

Suryadilaga, M. Alfatih, dkk., Miftahus Sufi, Yogyakarta; Teras, 2008. 